\title{
Impact of ground infection sources of cacao frosty pod rot on clon CCN-5I
}

\section{Abstract}

With the purpose to observe the incidence of Cacao Frosty Pod Rot on the production of clone CCN-51, 27 sporulated pods were laid around a tree within a circle of 50 radius centimeters on the ground. After two months and one week, only one pod was affected which occurred one week later from monitoring. This is atribuible to external air sources of infection. It can be affirmed that diseased pods deposited on the ground not constitute inoculum sources saving time and costs within disease cultural control

Keywords: cacao, disease, genom CCN-51, cultural control
Volume 3 Issue I - 2019

\section{Gabriel Cubillos, Nelson Ardila}

Specialist in buying and agriculture development University,

Colombia

Correspondence: Gabriel Cubillos, Designation Private assessor, Specialist in buying and agriculture development University, Carrera 86 No. 34-56, Medellín, Calle 73 No. 40W74, Bucaramga, Colombia, Email cubillos.g@gmail.com

\section{Introduction}

Cacao Frosty Pod Rot (Figure 1), Moniliasis in Spanish, severely affects the yields of cacao farms and the raw material quality in Central and South America. Actually its control has been focused towards the cultural management. However, there are yet controversial points about what to make with the diseased pods when are cutted off the trees that it constitutes a crucial aspect within the disease cultural control.

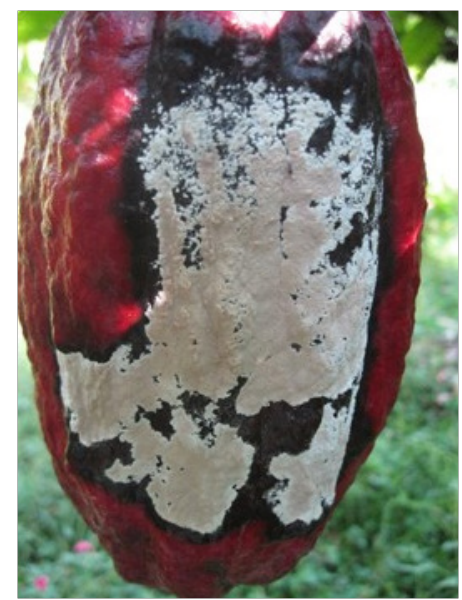

Figure I Typical signs of a pod affected by frosty pod rot.

\section{Materials and methods}

In the year 2005 in backyard of a house in the county of San Vicente de Chucurí (Santander department), Colombia SA, located in the Northeast of the country, at 800 meters on the sea level, with a rain mean of 1800 millimeters, $76 \%$ relative humidity and $24^{\circ} \mathrm{C}$ of mean temperature, they were found 4 cacao trees of 3 years old of clone $\mathrm{CCN}-51$ distant 1 kilometer of nearest cocoa trees. One of these trees, that had on its stem and branches pods of 2 - 4 months of age, was chosen for monitoring. Surrounding this tree, within a radius of 50 centimeters, on June 16,27 affected pods of Frosty Pod Rot were deposited on the ground, most of which were in profuse sporulative activity (Figure 2). Because the trial had no experimental design it is considered as a general observation.

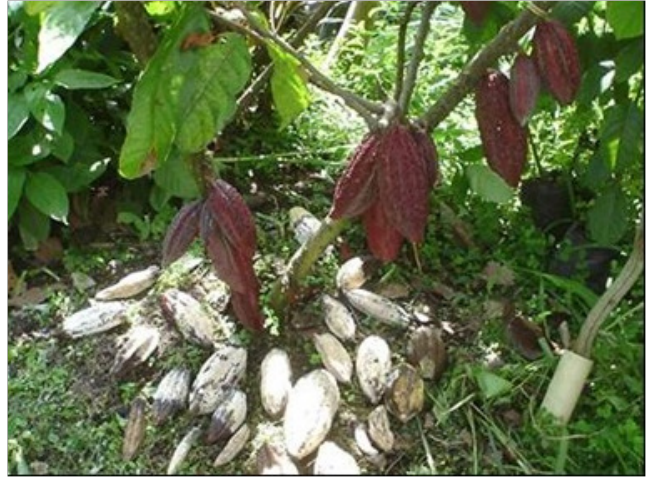

Figure 2 Sporulated pods with frosty pod rot laid surrounding a clone CCN5 I tree. Note that the tree has pods in growing of 2-4months age.

Having into account the time needed to observe the first symptoms, around 1 month, ${ }^{1}$ during two months the number of harvested pods in the tree was recorded to determine the degree of incidence of the disease and thus to know the impact of ground sources of infection.

\section{Results and discussion}

One week after the source of infection was placed 1 affected pod was harvested in brown spot stage (Figure 3); however, according to the disease cycle to observe this specific symptom should need two months ${ }^{1}$ by which this infection only can be attributed to external inoculum sources. Table 1 shows the results of pods harvested during the observation period.

Table I Record of pods harvested in the tree of clone CCN-5I during the observation period. Year 2005

\begin{tabular}{lllll} 
Date & $\begin{array}{l}\text { No. Frosty } \\
\text { pods }\end{array}$ & $\begin{array}{l}\text { No. Healthy } \\
\text { pods }\end{array}$ & $\begin{array}{l}\text { No.Total } \\
\text { pods }\end{array}$ & \% Incidence \\
\hline 23-Jun & 1 & 0 & 1 & 100 \\
30-Jun & 0 & 1 & 1 & 0 \\
August 4 & 0 & 5 & 5 & 0 \\
August 23 & 0 & 13 & 13 & 0 \\
Total & 1 & 19 & 20 & 5 \\
\hline
\end{tabular}




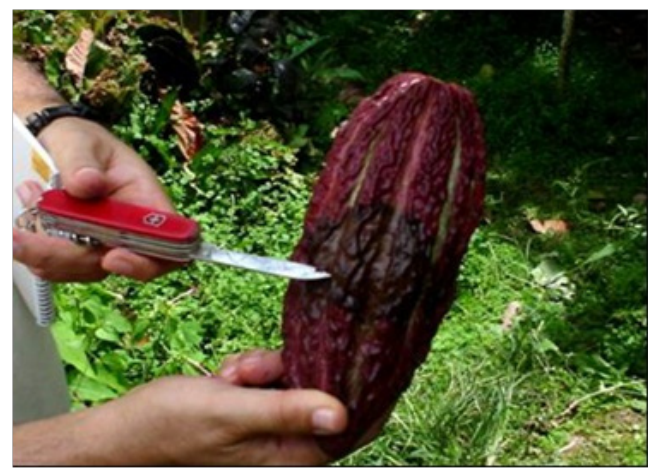

Figure 3 Pod in brown spot stage harvested one week after placing the infection source on the ground.

After the first pod with Frosty Pod Rot harvested in the first week, no more diseased pods were collected until the end of the observations. In Figure 4 it is possible to see the decomposition state of diseased pods deposited on the ground, black in color, and the way they are being buried by weeds and leaf litter. Moreover, it can be seen pods in ripe stage next to be harvested. Although the observations lacked repetitions it is possible to conclude that in the case described, the large sources of inoculum located on the ground were not able to generate infections and, consequently, the pods with Frosty Pod Rot removed from the trees can be left freely on the ground without any potential risks of infections. This result coincide with the founds and affirmations of Evans ${ }^{2,3}$ and Cubillos. ${ }^{4,5}$

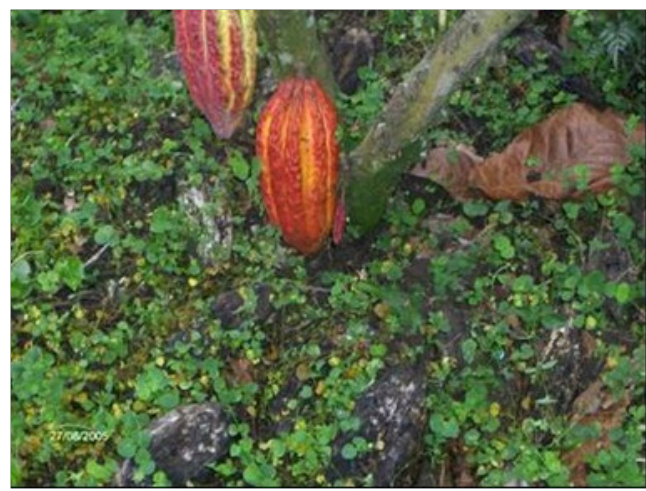

Figure 4 On the ground, it can be seen the black pods that were deposited 9 weeks ago as possible land-based sources of Frosty Pod Rot.
These results show the behavior of the diseased pods left on the ground like infection sources of Frosty Pod Rot on the clone CCN51 and allow to conclude that adopting this management practice the cultural control is more easy and low-cost.

\section{Acknowledgments}

None.

\section{Conflicts of interests}

The author declares there is no conflict of interests.

\section{References}

1. Rodriguez E, Mujica J, Cubillos G. Manejo integrado de la Moniliasis en el cultivo del cacao. Consejo Nacional Cacaotero. 2005.

2. Evans HC. Pod Rot of Cacao caused by Moniliophthora (Monilia) roreri Commonwealth Mycological Institute. 1981.

3. Evans HC. A Reassessment of Moniliophthora roreri (Monilia) Pod Rot of Cocoa. Cocoa Growers Bulletin. 1986;37:34-43.

4. Cubillos G. Exploraciones acerca de la importancia que tienen los frutos enfermos dejados en el suelo como fuentes primarias de infección de Moniliophthora roreri Cif. \& Par.). El Cacaotero Colombiano. 1981;(18):38-43

5. Cubillos G. Control de la Moniliasis del Cacao causada por Moniliophthora roreri (Cif. \& Par.). 2018. 